\title{
Linguistic Typology of the Limbu Mundhum: A Diglossic Case
}

\author{
Mohan Kumar Tumbahang, $\mathrm{PhD}$ \\ Associate Professor \\ Department of English, Mahendra Multiple Campus, Dharan, Tribhuvan University, Nepal \\ Email: mkt2019@gmail.com
}

DOI: https://doi.org/10.3126/dristikon.v10i1.34557

\begin{abstract}
This paper aims at looking into varieties of the Mundhum language and reasons for its intricacies to the Limbu natives. The study attempts to follow the qualitative research design which involves collecting non-numerical data especially the religious text or discourse for analysis and interpretation. After the related data were collected, the linguistic theory specifically linguistic typology is used to analyze, compare and interpret them. The findings of this study indicated that the Mundhum or the religious scripture of the Limbu community does have a specific language variety which emerges out from the diglossic situation. According to the diglossic situation, the Mundhum serves as the high variety. This high variety is employed in formal social functions and ritual performances. To the contrary, the ordinary language variety of Limbu is used in every day communicative purposes and this type of speech variety is considered to be low variety in the sociolinguistics' field. There are certain reasons which make it very complicated to the natives to comprehend the Mundhum. Inquisitive individuals in the study of typological linguistics of the religious text are expected to get help from this study.
\end{abstract}

Keywords: diglossia, language variety, linguistic typology, Mundhum language

\section{Introduction}

Nepal is noted for its multi-ethnicity as well as multilingual situation. One of the dominant ethnic groups is the Limbu which possesses its own language, script, culture, religion and geographical territory. Grierson (1909), the famous British linguist states, "The Limbus are one of the principal tribes of eastern Nepal" (p. 283). He further argues that they inhabit in the hilly region traditionally known as Pallo Kirant or Far Kirant. But Das (1896) holds a bit different view on the ethnonym of Limbus and states, "They designate themselves by the name Yak-thung-ba and their language by the name Yak-thung-ba Pa:n" (p. 31). Like Das, van Driem (1987) opines, "Limbu' is Nepali ethnonym and the homeland in eastern Nepal is known in Nepali 'Limbuwan" (p. 50). He expresses his denial over Campbell's (1940) reference that the term 'Limbu' to be Gurkha corruption of the autonym 'Ekthoomba' (p. 595). Regarding the linguistic position of the Limbu, Weidert and Subba (1985) maintain, "Limbu must be considered the dominant and most important language of the Kiranti group of the TibetoBurman languages in terms of numbers of speakers and in terms of the vastness of geographical distributions" (p. 1). In the same way, the view of Ebert (1997) can be cited here as she opines, 
"It has a considerable number of speakers and a writing system of its own. The script is known as 'Sirijanga' and it has a number of books on various disciplines" (p. 11). She means that the Limbu language is a more developed language in comparison to other Tibeto-Burman languages spoken in Nepal.

The Limbu original speaking area, as for Kainla (2059 VS), "spreads from the Arun River in the west to the Tista River in the east" (p. 9). This area includes the districts such as Sangkhuwasabha, Terhathum, Dhankuta, Sunsari and Morang in Koshi zone and Taplejung, Panchthar, Ilam and Jhapa districts in Mechi zone and some adjoining states of India like Sikkim, West Bengal, Assam and Meghalaya. G. B.Tumbahang (2007) holds the view that in course of time, the Limbu have migrated from their original abodes to different places. He further states that they are found in Kathmandu, Lalitpur and Bhaktapur districts of mid-Nepal. Pokhrel (2050 VS) has the similar view as Kainla and states that Limbu language is basically spoken in the area between Koshi and Mechi zones of eastern Nepal. According to Central Bureau of Statistics (CBR) (2011) the total population of the Limbu is 387,300 which is $1.46 \%$ out of total population of the country. Out of them, 343,603 speak their language which is $1.29 \%$ out of total nation's population.

In Nepal, there are four language groups namely Indo-European, Tibeto-Burman, Austro-Asiatic and Dravidian. Among them, the Tibeto-Burman family is in the dominant position in terms of its number of languages it includes. The CBR (2011) has listed out 123 different mother tongues currently spoken in the country out of which 66 languages fall under the Tibeto-Burman language family. Among these 66 languages only three languages such as Newari, Limbu and Lepcha/Lapcha possess their own scripts. The Limbu language can be ranked in the second position in terms of its language as well as its literary development.

The Limbu natives employ two distinct varieties of speeches that is, 'practical speech variety' which is used in the day-to-day communicative purpose and 'ritual speech variety' that is used in special ritual performances. This variety is usually found in the verse form and it is recited on the special occasions. The Limbu natives, who designate themselves as 'yakthung/ yakthungba,' regard this diaglossic form as 'Mundhum' to which Subba (1995) maintains, "the collective form of legends, folklores, prehistoric accounts, sermons, shamans, moral or philosophical exhortations, etc. in the poetic language" (p. 3). He means that Mundhum comprises the matters of illness healing to spiritual dealings. Mundhum provides the Limbu natives with insights into the inner complexity of life. In this regard, Subba (1995) writes, "Mundhum is the source of inspiration, information and enlightenment for the Limbus and the way of life, customs, and rites-de-passages are guided by it," (p. xiii). Subba seems to hold the opinion that Mundhum is the course that directs the life journey of the Limbu ethnic people. Likewise, for Gaenszle (2000), "Mundhum is oral tradition, ancestral knowledge and more specifically traditional way of life referring to the moral order established in primordial times" 
(p. 31). Mundhum is thus corpus of mores, codes, conduct and ethical values concerning both the matter and soul of the Limbu community.

In sum, the 'Mundhum' refers to a collective form of the religious discourse of the Limbu ethnic community. This exhibits the most classical form of the Limbu language which is believed to have transmitted through oral tradition from the time immemorial. The Mundhum is not commonly used to serve the day-to-day communicative purpose. Rather it is employed on special events and ceremonies or rites and rituals. A very few Limbu people (i.e. Limbu priests) are familiar with this sort and they are supposed to recite and interpret the Mundhum. This implies that Mundhum remains to be unintelligible to a considerable number of the Limbu natives.

So far as the previous writings about the Limbu Mundhum are concerned, there are very few linguists who have discussed about the linguistic features of this very religious text. The native writers as Kainla (1991), Angdembe (2012) and Tumbahang (2013) have discussed on the Mundhum language in general. Similarly, the foreign writers like Nicolas J. Allen, Martin Gaenszle and Martino Nicoletti have written on the ritual language of the ethnic communities of Nepal. But when one considers the writings about the indigenous people's ritual language of other countries besides Nepal, there are many writers who have analyzed the features of the ritual languages. To name few of them are Jan (1963), Gevirtz (1963), Emeneau (1974), Kuipers (1990), Staal (1996), Bell (1997), Keane (1997), and Fox (2014). The above mentioned linguists have analyzed specially the linguistic features of the religious texts of various indigenous tribes. Their writings are more or less helpful to analyze any ritual discourse or the religious texts of any tribe of the world.

\section{Methodology}

The study is qualitative in nature since it involves annotation, analysis, interpretation and explanation. This research work is primarily based on the Limbu Mundhum text (discourse), or the religious scripture mostly found in the poetic form. The related materials were obtained through print and online sources. The sources of textual references such as published and unpublished works, documents, reports, manuscripts, pedigrees, books, booklets, journals and magazines related to the study were consulted, recorded and reviewed as the secondary resources. They include linguistics more specifically linguistic typology which can be reliable insights to comprehend and expound the issue raised in this study. The language varieties between the 'practical language' (everyday conversation) and the Mundhum language are distinctly different. In order to trace down the marked differences between these varieties and demarcating features, first of all, I studied the related books on sociolinguistics as a basic theory and got theoretical insight into the study area. Thereafter, I listed down the basic linguistic items (i.e. sonic feature, meaning system and syntactic structure) and paralinguistic 
features to distinguish these two varieties. Basing on the said linguistic aspects, I attempted to analyze and explain as how they are different from one another.

Having thought over the nature of the study as content analysis, the researcher opted the purposive or selective sampling procedure. The samples have been selected from the population through researcher's intuition or on some certain subjective bases. The selection is not random because it is deliberate and purposive. The obtained data have been dealt with the descriptive analysis. This sort of analysis has been applied in terms of two variables (i.e. ordinary language and the Mundhum language). In this context, the researcher has worked out the specific measuring relationship between two aspects. As has already been mentioned the the Mundhum is the religious text, the area of the study is the 'classical language' under sociolinguistics.

\section{Results and Discussion}

In this paper, the major focus is given on two aspects: the assessment of the linguistic variety of the Limbu Mundhum and the causes of unintelligibility of the Mundhum to a larger number of its natives.

\section{The Language Variety of the Mundhum}

The Limbu community generally makes use of two distinctly different varieties of the Limbu language. The use of the particular kind of variety depends on the context and situation. The Mundhum variety is employed on the special occasions and mostly the ritual performances by the Limbu priests like Phedangba, Samba, and Yeba in the Limbu native term. The Limbu rituals comprise the performance prior to the infant's birth natively known as 'Sapok Chomen' (a ritual wishing successful delivery of a child/a worship of the pregnancy), 'Yangdang Phongma' (naming of newly born baby), 'Tendham Mekhim Lokma' (matrimonial rites) and under the death rites 'Net Yukma' (mourning rite), and 'Khauma' (cleansing rite). In this way, the Mundhum variety within the Limbu language, serves as a special means for dealing with the rituals.

Unlike the Mundhum variety, 'the practical variety' as referred to by the Russian literary theorist, Shklovsky (1893-1984) is used in the day-to-day communicative purpose. This variety possesses remarkably a larger number of speakers than the Mundhum variety. The communicative language variety is casual in its form having simple laymen's vocabulary. The simple vocabulary implies that the words, phrases, idioms and chunks are plain or straightforward enough to the commoners. Likewise, the basic feature of the communicative language is its prosaic structure in the expression.

While looking into the linguistic features of the Mundhum variety, there appears distinctly different from the language variety used in the practical language or communicative language. Hudson (1999) maintains that the language variety which is used in special purposes 
is, in fact, a high variety in a 'diglossic' situation. When the context of the Mundhum use is considered, it readily seems to be the 'high variety' because the same Limbu language speaking people use these two varieties according to the situation and the Mundhum variety appears to be higher standard in comparison to other. The high variety (i.e. Mundhum) and the low variety (i.e. general communicative variety) are not two different languages used by separate language community but they are the varieties of the same language community. However, the diglossic situation occurs even when two separate languages are used on the basis of this context. The example of such situation can be found in the use of Nepali and Sanskrit. The Aryan community in Nepal uses Nepali in the day-to-day communication whereas Sanskrit in special purposes.

In sociolinguistics, the term 'diglossia' is defined as a situation in which two languages (or two varieties of the same language) are used under different conditions within a community, often by the same speakers. The term is usually applied to languages with distinct 'high' and 'low' (colloquial) varieties, such as Arabic. This situation occurs in the Limbu community as the native speakers use explicitly different varieties on certain occasions. For the term 'diglossia', the credit goes to Charles Albert Ferguson (1921-1998) one of the founders of sociolinguistics since he was the first man to introduce this concept in English language literature, observing the situation found in Greece. Discussing on the same matter, Hudson (1999) refers to it that in some societies there are two obvious varieties sufficiently distinct for lay people to call them separate languages of which one is used on formal and public occasions while the other is used by everybody under normal everyday circumstances.

The Limbu community using two varieties of the same language on the basis of context or situation meets the criteria that are put forward by Holmes (2008) a New Zealander sociolinguist. She maintains these bases as follows:

a. Two distinct varieties of same language are used in the community with one regarded as the High (or $\mathrm{H}$ ) variety and the other Low (or L) variety.

b. Each variety is used for quite distinct functions; $\mathrm{H}$ and $\mathrm{L}$ complement each other.

c. No one uses the $\mathrm{H}$ variety in everyday conversation. (p. 27)

Like the aforementioned views, Yule (1995) holds the opinion about the 'diglossia' as, "to describe a situation in which two very different varieties of language co-exist in a speech community each with a distinct range of social function" (p. 195).

From the foregoing statements of the sociolinguists, the Limbu Mundhum can be said to be the high variety used for special purposes of formal and ritual performances. It implies that the Mundhum is essentially different from that of the everyday conversational language variety. Moreover, it is a special language variety of the Limbu natives which is used in the liturgical expressions or interactions. The liturgical expression further includes the speech acts 
like invocations, petitions, doxologies, intercessions, thanksgivings, rosaries, litanies, chants, hymns, psalms and canticles (Crystal, 2007, p. 389).

\section{Reasons for Mundhum's Complexity to Limbu Natives}

Mostly, the Mundhum corpus is available in the poetic form. This can be the obvious difference from the practical prosaic language of the everyday communicative speech. The Mundhum variety has explicit linguistic features which can cause much difficulty to the commoners. These specific linguistic features are briefly discussed underneath:

\section{Linguistic Deviation}

Language deviation in this regard refers to the breaking of the ordinary grammatical norms and rules in the speech or in writing. This phenomenon proves to be one of the major causes in making the expression or discourse incomprehensible to the readers or listeners. Pointing to this intricacy of poetry, Crystal (2007) views as, "Authors take risk when they push language to its limits. If they break too many rules, they can fall over the edge of language into unintelligibility,"(p. 72). Likewise, Pope (2010) views about how poetic language differs from the ordinary language as, "poetry both disturbs and reforms the pattern of routine language" (p. 89). The Mundhum being poetic expression, the deviation is commonplace and thus undecipherable. In the Mundhum, the case of linguistic deviation is noticed in three major areas which are given below:

Sonic texture (deviation in phonological level). Sonic texture denotes that sounds in poetic expression are arranged in a particular sequence so as to intensify meaning to the audience. To this point, Lazar (2004) holds the opinion as, "It (Poetry) patterns sounds and orders rhythms" (p. 98). Generally, the Mundhum gets expressed through recitation in rhythmic melodious pattern. The sound arrangement in the Mundhum form has to do much with the mental impression created by series of sounds. There is a greater correlation between sounds and meaning in the poetic expression. In this regard, Pope (1991) rightly opines, "The sound must seem an echo to the sense" (p. 120). Here, Pope implies that the sounds correlate the meaning in the poetic expressions. For this reason, the Mundhum is recited in a proper rhythmic balance but not said just as in the casual conversation. The question may arise as how the Mundhum deviates from the ordinary norms of the grammar. Its reply can be made by the counter question as 'Does anyone sing or express the verse lines while in the everyday conversation?' Presumably enough, no one communicates by singing in an ordinary speech situation. Hence, the Mundhum has defied the norms of grammar in terms of phonic pattern.

Certain linguistic items are deliberately repeated in order to enhance the musical quality of the verse. Let us consider the following examples:

1. a $k^{h} u n \varepsilon$ ment ${ }^{\text {sh }}$ am tsogusi japmi tsogusi 


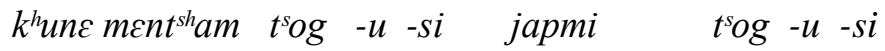

$\mathrm{s} /$ he human make-3P-nsP human being make-3P-nsP

He created human beings.

b jukphuj ambeknen lo saway ambeknen lo

jukphuj a-m-bek-nen lo saway a-m-bek-ncn lo

forest 1-NEG-go-NEG-ASS hunting 1-NEG-go-NEG ASS

Simply, no one goes on hunting.

In the above two verse lines $k^{h} u n \varepsilon \quad m \varepsilon n t^{\text {sh }}$ am $t^{s}$ ogusi; japmi $t^{s}$ ogusi and jukph uy ambeknen lo; saway ambeknen lo each line has been separated by caesura almost into two halves. Each half has got the equal number of syllables except the beginning word ' $k^{h} u n \varepsilon$ ' which is only an 'offbeat' (i.e. not coinciding with the regular beat). The linguistic sounds have been arranged in such a way that they happen to create musicality because the ending words of each half are the same $t^{s}$ ogusi $=t^{s} o g u s i ; l o=l o$. Not only this, many sounds are identical between two halves. Why this kind of expression differs from the ordinary speech is that people do not sing in their everyday conversation. While in singing, as everyone realizes the individual sounds may take longer duration than they are pronounced in the simple conversation. Furthermore, supra-segmental features like pitch, tone, stress and juncture are excessively used in the recitation.

Lexical meaning (deviation in Lexical semantics/ word meaning). Generally lexical meaning refers to the word meaning or the meaning denoted by the dictionaries. This kind of meaning is also known as the primary or denotative meaning of a word which shows the relationship between the words and objects in the world of experience. For instance, 'a rose' in its primary meaning denotes a kind of woody perennial flowering plant of a genus 'Rosa'. But when it associates the meaning of a beautiful young lady, love, prime youth, transient or the like, it is not the primary (literal) meaning of the 'rose' rather it is secondary (figurative) or connotative meaning. In the figurative meaning, one moves beyond and above the literal meaning and when a word leaves its primary meaning, it rises up to call for multiplicities of associations. This kind of associative meaning is semantic deviation. Thus, the usual dictionary meaning is deviated and that suggests something else.

While talking about the Limbu Mundhum, it is essentially distinct from the ordinary or practical language variety in that, it activates secondary or collateral meanings of a word. The Mundhum is found to be freely exploiting the figures of speech in the expression where the figures are a kind of deviation against the rules and norms set by the grammar. In this regard, Bain (1866) opines that a figure of speech may be a deviation from the plain and ordinary mode of speaking for the sake of greater effect. Most of the lexical items in the Mundhum are not 
designed for the primary meaning but the vocabulary is especially for the associative meanings. When the words are not used to denote the dictionary (primary) meaning, it is technically called as semantic deviation.

The Mundhum uses the ordinary lexical forms too, but they are semantically deviated from their usual meaning. Let us consider the following example:

\section{Ordinary speech form}

ja:ysa: kundhe $\leftrightarrow$ wealth, property

ja:yben $\leftrightarrow$ a kind of moss

$s \varepsilon d^{z} O \leftrightarrow$ beer in its initial stage,

pehi $\leftrightarrow$ placenta

\section{Mundhum (Ritual) form}

ja:ysa: kund ${ }^{h} e \leftrightarrow$ what, how

ja:yben $\leftrightarrow$ lap

$s \varepsilon d^{z} O \leftrightarrow$ move or turn

$p \varepsilon h i \leftrightarrow$ dance in circle/fly

Word order (deviation in sentence structure). Word order is another deviation occurred in the Limbu Mundhum. This means that the words are not ordered as prescribed in the language grammar. So-called random at word order results from the idea of the poet's foregrounding as well as backgrounding the specific notion. This kind of distortion is pervasive in the Mundhum because the poets are said to have the poetic license that is, they are held at certain liberty to distort/break the established norms of grammar. Abrams (2000) forwards Dryden's definition as the liberty which poets have assumed to themselves in all ages of speaking things in verse which are beyond the severity of prose. By availing the poetic license, "poets reorganize syntax, invent its own vocabulary, freely mix register and create its own pronunciation. Poetry draws creative on a full range of archaisms and dialects and generates vivid new metaphors" (Lazar 2004, p. 98). Likewise, Leech (2008) holds the opinion that this is the reason that poetry has been characterized deviating from the norms of language. Regarding this violation of rules, Widdowson (1983) argues that poetry frequently breaks the rules of language but by so doing, it communicates with us a fresh, original way. The violation of the established linguistic rules does not necessarily mean that it creates obstacle in the communication rather the meaning is surcharged by a new way. A single innocent looking line is laden with multiplicity of meanings. In other words, an expression is resounding and echoing diverse meanings. In this way; the expression becomes more vivid and graphic as well.

When we look up the syntactic structure in the Limbu Mundhum, we find the example of distortion of rule in the sentence level. Especially, syntactic or grammatical deviation occurs in poetry in terms of words' combination that is, unusual collocation, inverted word order, marked parallelism, ellipsis, etc. Let us have a look at the following verse lines of the Mundhum:

$\begin{array}{ccccccc}\text { 2.a je.. iksa pokse } & \text { ro } & k^{h} \text { ambe:kpokse } & \text { ro } & \\ \text { je iksa poks } & -\varepsilon & \text { ro } & k^{h} \text { ambe:k poks } & -\varepsilon & \text { ro }\end{array}$


VOC earth become -PT ASS land become -PT ASS

The earth was created.

$\mathrm{b} \quad$ je ... minu buymaha? tignam buymaha?

je ... minu buyma -ha? tinnam buyma -ha?

VOC APP plant $-\mathrm{p}$ cane plant $-\mathrm{p}$

Fine cane plants,

Of the given examples, the verse lines have explicitly violated the ordinary linguistic norm by the marked parallelism and unusual collocations. Syntactic parallelism has been achieved by maintaining the similar length and lexicon between two halves of the verse. Similarly, the pre-modifiers ' $m i n u$ ' and ' $i k s a$ ' are unusual lexemes in terms of the ordinary speech. Though being so, the lines are fully successful to communicate. They are attractive and catchy as well since they have de-familiarized by doing so. The concept of de-familiarization was developed by one of the Russian Formalists, Viktor Shklovsky (1893-1984). He means, "defamiliarization is to make fresh, new, strange, and different what is familiar and known" (Cuddon 214). Cuddon states "through de-familiarization the writers modify the readers/listeners habitual perceptions by drawing attention to the artifices". He further adds that "this is a matter of literary technique. What the listeners/readers notice is not the picture of reality that is being presented but the peculiarities of the writing itself." To make the matter pretty clear, Cuddon (1998) quotes Shklovsky's (1917) writing from his 'Art as Technique' as follows:

The purpose of art is to impart the sensation of things as they are perceived, and not they are known. The technique of art is to make object unfamiliar to make forms difficult, to increase the difficulty of length and perception, because the process of perception is an aesthetic end in itself and must be prolonged. Art is the way of experiencing the artfulness of object; the object is not important. (p. 214)

The matter of syntactic deviation is not complete in disordering the words' sequence in sentence structure and unusual collocations but it still proceeds onto other aspects like selectional restrictions, contradiction, anomaly and tautology.

Apart from the above three major aspects of language deviation, there are other linguistic as well as paralinguistic cases which are equally responsible for the intricacy in the Mundhum comprehension. They are briefly referred to as follows:

\section{Language Related Factors:}

Highly classical or stereotypical language. The available Mundhum corpus is extremely classical type. The Mundhum exploits refined terms and richly ornate style. It neither entertains any addition nor any deletion from it. In this regard, Cuddon (1998) states, "Nothing 
can be taken away from it or added to it without doing injury" (p. 139). This rigidness really poses the natives in difficulty. Regarding the sternness of such languages Campbell (2004) holds the opinion that "ritual language requires exact verbal performance," (p.83). In his article entitled "The History of Linguistics' he further says that while no change was acknowledged in formal Arabic after the eighth century the realization that the spoken Arabic of the eighth and ninth centuries was charging stimulated the development of Arabic grammatical study. The Mundhum being a ritualistic language is found to be the stereotypical form away and untouched by the flow of linguistic changes. But this unravished (pure) position, through time immemorial unfortunately, pushes the classical language to the verge of extinction and unintelligibility.

The gap between the day to day communication and classical language widens horribly. The reality and mostly the fate of the classical language is to be limited to liturgical forms like hymns, petitions, doxologies, intercessions, thanksgivings, rosaries, litanies, chants, psalms, canticles, incantation, prayer, invocation; ritual forms like baptism, weddings, funeral, cleansing rites, exorcism, blessings; and private affirmations like ecstatic prayers, prophesying, spirit possession and so on. The Mundhum language is therefore, obscure, strange and also sublime only because it employs the ancient forms and terminologies. In this regard, Angdembe (2004) refers to Dahal's (1999) Nepali example of incantation in which the terms are unusual for average Nepali native speakers both for the ordinary and the intellectuals. The incantation 'mantra' (Mundhum) reads as 'Kaali: kukaadaaki tepri kaan, gangaa dunoi! gangaa dunio!! gangaa dunio!!!' This 'mantra' very easily confuses the modern people as to which language either Nepali or Hindi, it belongs. It is thought to be classic for it has employed the classical terms. Let us consider two Mundhum verses containing the stereotypical or classical form of language as follows:

3.a je...ettshum ni pok ${ }^{h}$ be $\quad e^{\text {sp }}{ }^{h} a$ ni pok ${ }^{h}$ cbe

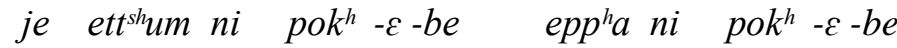

VOC how CTR happen -PT -INQ what CTR happen -PT -INQ

What has happened to the baby?

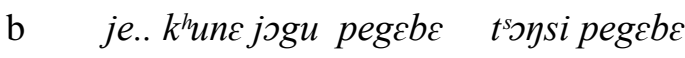

je $\quad k^{h} u n \varepsilon$ jogu peg $-\varepsilon-b \varepsilon \quad t^{s} \supset$ - si peg $-\varepsilon-b \varepsilon$

VOC s/he breath go -PT -NOM BAL-die go -PT -NOM

Succumbed to death.

The two verses $3 . a$ and $b$ in the ordinary language variety can rightly expressed as the exponents like $t^{\text {he }}$ pokes? (What has happened?) and $s i-\varepsilon$ (died). Here, the stereotypical form uses not only long roundabout way but also the obsolete terms like ettsh $\mathrm{tm}^{\mathrm{s}}$ epp ${ }^{h} a$ for 
interrogative pronoun 'what' $\left(t^{h} e\right)$ which are never used in the practical language. Likewise, the terms like jogu, $t^{s}$ כy-si are never used to suggest 'die' (si).

Archaic language. Obsolete and old-fashioned dictions are commonplace in the Mundhum discourse which may be quite unfamiliar with the common people. If we consider the Mundhum language there are plentiful examples of archaic dictions. For example:-

4.a allo iksa $k^{h} \varepsilon m m a ?$ go $k^{h} a m b e: k k^{h} \varepsilon m m a ?$ go

alls iksa $k^{h} \varepsilon m-m a ?$ go $k^{h} a m b e: k k^{h} \varepsilon m-m a ?$ go

Now land suit -INF TOP earth suit -INF TOP

Now to suit the earth,

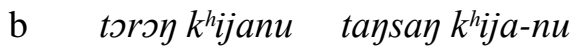

torsy $k^{h i j a-n u}$ taysay $k^{h} i j a-n u$

heavenly hound-COM sky hound - COM

The dogs from the heaven and the sky.

The question as to what makes the above lines different from the ordinary speech, can be answered only after considering the excerpt very keenly. There are terms (premodifiers which are essentially classical) added to the certain nouns which are not necessary in the ordinary conversation. The additional terms are never expected in the everyday conversation Let us see below:

\section{Ordinary speech}

$k^{h} a m-b e: k$ (earth/ land)

surit/ sammit (wind)

wa:hit (rainfall)

ja:pmi/mona: (man)

ta:ysa:y (sky)

\author{
Mundhum version

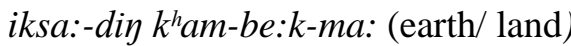 \\ surit kezoy (wind) \\ poygen-diy wa:hit (rainfall) \\ ment ${ }^{\text {sh }}$ ::m-gen na:m ja:pmi(man)

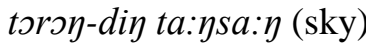

The above underlined terms are additional which create complexity in the meaning. They collocate with other preceding or following terms only to make high-sounding or sublime expression. Obviously, the underlined terms are out-dated terms in the speech. If they occur separately, most of them have not got specific meaning. They are more often treated as bound morphemes in terms of lexical meaning because they do not issue a particular meaning in isolation.

Symbolic expression. Using the symbol in the lofty writing like Mundhum is very usual phenomenon. Which symbol stands for what is very complex matter to trace out the meaning. Mostly the Mundhum is built on the multiplicity of myths. These myths are full of 
symbols. The process of demytholization is extremely tough job for average natives. Let us consider the following verse lines having the symbolic meanings:

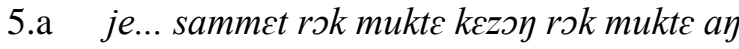

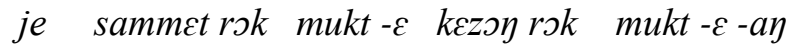

VOC breeze FOC blow -PT wind FOC blow -PT pfG

She was constantly blown by the wind.

b mikki $p^{h} \varepsilon k t-\varepsilon-t^{\text {shi }} p^{h} u \eta w a$ p $p^{h} \varepsilon k t \varepsilon t^{\text {shia }}$

mikki $p^{h} \varepsilon k t-\varepsilon-t^{s h} i \quad p^{h} u \eta-w a \quad p^{h} \varepsilon k t-\varepsilon-t^{s h} i-a \eta$

life bloom-PT-dPS flower -BAL bloom-PT-dPS-pfG

They copulated.

In the above example, the terms sa:mmet and $k \varepsilon z \ni y$ (wind or air) and $p^{h} u \eta w a$ : (flower) are not for the literal meaning but for the symbolic meanings which symbolize as masculine potency and erotic youth respectively. It is so because the first mother Muzingna:ma: was supposed to have conceived by the 'wind'. Similarly, $p^{h} u \eta w a: p^{h} k$-ma:? (literal meaning 'flower blooms') suggests 'coition'. Therefore, these usages of the terms are essentially symbolic.

Formal language. Here, the term 'formal' refers to the type of diction used and syntactic structure in the particular expression. There are layers of lexical items and syntactic pattern to denote the same object or notion differently. The use of certain diction denotes the degree of formality. For instance, the three terms like 'fire', 'flame' and 'conflagration' suggest the same thing but they cannot be used in the same degree and context or situation. In the Limbu Mundhum, as Tumbahang (2013) states, "the sun (na:m) has five different naming terms (i.e. miwa: lenzoma:/miwa: kuna:m/lenda:ngen na:mba:/na:m ziri na:mla:k/na:dhung $n a: m l a: k) "$. In this situation, most natives find themselves unable to sort out right kind of term in the right context.

Likewise, as one considers the Mundhum language, even a single observation is is enough to draw the conclusion that the language variety it employs is essentially distinct from the ordinary variety used in everyday communication. In an ordinary mode of speaking the 'man' is called as 'ja:pmi' (Panchthare dialect) 'msna:' (Phedape/Taplejungge dialect), na:pmi (Chhathare dialect) but in the Mundhum language, it has only one common form for all the four

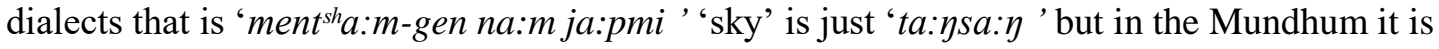
'torsy-diy ta:ysa:y'. Therefore these two examples reveal that the Mundhum language is highly formal setting itself off the ordinary form. 
Frequent use of unusual affixation. The Limbu language is characterized as agglutinative language. Basing on this feature, the Mundhum makes use of atypical or uncommon affixation and the affixes are not used at random manner but certain words take some specific affixes. Supplying proper kind is too much difficult task. For example, -ken/-gen, -ding, -minu and the like are some suffixes that the Mundhum exploits, and they are never used in the ordinary conversation.

The Mundhum language rarely uses the headword without its appositive/modifier word. This means the headword most often co-occurs with modifying word. Again the same headword takes multiple modifiers. Let us see the example below:

\begin{tabular}{|c|c|}
\hline \multirow{5}{*}{$\begin{array}{l}\text { Ordinary speech form } \\
\text { mikwa: (tear) }\end{array}$} & Mundhum (Ritual) form \\
\hline & tsmen-diy mikwa: \\
\hline & 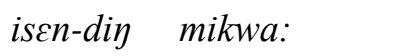 \\
\hline & meriy-gen mikwa: \\
\hline & sa:-meriy mikwa: \\
\hline \multirow[t]{4}{*}{$t^{h}$ sk (body) } & tsmsa:y-diy ja:m-be \\
\hline & $a: b u-d i \eta / g c n k u-d^{h} \jmath k$ \\
\hline & ka:ppa: ja:m-be \\
\hline & na:sin-gen $t^{h} \supset k$-la: \\
\hline
\end{tabular}

The variation of the modifier indicates the variation in the context. The all modifying words of the headword mikwa: 'tear' cannot occur in the same context. The modifier 'meriy' refers to sorrow or lamentation. Likewise, 'iscn' presumably denotes reminiscence or symbol or souvenir and ' $t$ ' $\supset m \varepsilon n$ ' literally means sharp or critical.

Recurrence of bound lexemes or nonsensical words. While reciting the Mundhum, one can find plenty of words without any meaning. Such words with the zero meaning are termed as bound lexemes or nonsensical words. These zero-meaning-words put the audience in maze. Crystal (2007) also mentions about such words in the oral poetry as "Unintelligible words and phrases are commonplace in the oral poetry in many languages and can be explained only by a universal desire to exploit the sonic potential of language" (p. 11).

In the Limbu Mundhum verse, the bound offbeat can be ' $y e$ ', 'hey', hary $\tilde{u}$, pãy $\tilde{u}$, etc. They usually occur at the beginning. The verse final occurring offbeats are ' $r o / l o, p^{h} a \eta$, ' $b e$ '. The initial occurring offbeats have a higher frequency than the verse final. The lexical (meaningful) offbeats usually involve adverbials like 'allo, and $: n, o k k^{h} \varepsilon, t^{h} O$ : and pronouns like 
$k^{h} \varepsilon_{n} i, k^{h} u n i$, and so forth. Let us consider the example of non-lexical offbeats used in the Mundhum verse line:

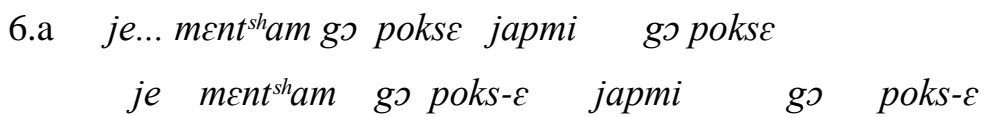

VOC human then become-PT human being then become-PT

It has become human anyway.

b je.. sa:ygu agere sokma: agere

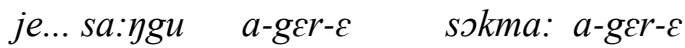

VOC vitality 1-get-PT life force 1-get-PT

We are refreshed having rest.

In the above verse lines, the verse-initial offbeat ' $j e$ '..., has been employed. The offbeat ' $j e$ ' is essentially non-lexical or nonsensical.

\section{Paralinguistic Factors:}

Temporal factor. The Mundhum explanations and references are related to the remotest past or the time immemorial. Things, concepts, tastes and understandings must have drastically changed in such wide period's gap. The thing and situation referred to in the scripture may not have any existence or may have changed completely to data. So understanding the scripture thoroughly can only be just like the false hope or perceptive illusion.

Pedagogical provision. Many religions in the word have clear provision to preach the liturgical contents and language structure. The Limbu community neither had such provision of teaching religious language structure in the past nor has it in the present. But surprisingly, this ethnic community has got a strong belief that acquiring the linguistic ability in the Mundhum is beyond the mortal beings' reach but it is bestowed upon certain persons in accordance with the divine wish. This being the reason, there are no such formal classes for imparting the Mundhum contents and linguistic knowledge in the Limbu community. Those who are supposed to have the competency at the Mundhum language, they are found to be reluctant to share the idea among other enthusiastic individuals. This circumstance is perhaps increasing the degree of obscurity in the Mundhum. Thus, the glorious Mundhum language is slowly but incessantly perishing away from the Limbus' cognitive domain.

\section{Conclusions}

The Limbu ethnic people residing in their traditional abodes in the eastern part of Nepal use two language varieties for different purposes. This type of situation is called as 'diglossia' in which two varieties of the same language are used under different conditions 
within a community, often by the same speakers. The Mundhum language variety is used in only formal programs and ritual performances and thus it is basically the religious discourse. The Mundhum language variety is considerably distinct from the ordinary language variety in terms of the sonic pattern, meaning system (semantics), and the syntactic pattern. Furthermore, there are certain factors setting the Mundhum variety off the ordinary speech variety. A significantly larger number of Limbu natives is not familiar with the Mundhum language or there are some basic causes behind the Mundhum's complexities. These complexities arise chiefly from the linguistic deviations, distancing time between the Mundhum references time and the audience's time, and no provision for imparting Mundhum contents and language structure among the natives.

\section{References}

Abrams, M. H. (2000). A glossary of literary terms (7th ed.). Gopson Papers.

Allan, N. J. (1978). Sewala Puja Bintila Puja: Notes on Thulung Ritual Language. Kailash: A journal of Himalayan studies. 6 (4), 237-256. Ratna Pustak Bhandar.

Angdembe, T. M. (2004). Mundhum: murkhako bhasha ki purkhako bhasha? Tongsing. 3 (1), 26-27. Kishor Limbu, Sangbahangbhe.

Angdembe, T. M. (2012). The classical Limbu language: Grammar and dictionary of a Kirat Mundhum. Nepal Academy.

Bain, A. (1866). English composition and rhetoric: A manual. Longmans Green and Co.

Campbell, A. (1940). Note on the Limbus and other hill tribes hitherto undescribed: Journal of the Asiatic society of Bengal, 9 (102), 595-615.

Campbell, L. (2004). The history of linguistics. In Aronoff, M. \& Rees-Miller, J. (Eds.), The handbook of linguistics. (pp. 81-104). Blackwell.

Crystal, D. (2007). The Cambridge encyclopedia of language (2nd ed.). CUP.

Cuddon, J. A. (1998). A Dictionary of literary terms and literary theory (4th ed.). Maya Blackwell.

Das, K. (1896). The Limbu of Kiranti people of eastern Nepal and Sikkim. The journal of Buddhist society of India, 9, 31-34.

Ebert, K. (1997). A Grammar of Athpare. Nunchen New Castle.

Ferguson, C. A. (1959). Diaglossia." Word. (pp.325-40). Vol. 15 Issue II. Reprinted in Pier Paolo Giglioli ed.1972: Language and social context. (pp. 232-51). Penguin.

Gaenszle, M. (2000). Origin and migrations: Kinship and mythology and identity among the Mewahang Rai of east Nepal. Mandala Book Point. 
Grierson, G. A. (1909). Linguistic survey of India. Vol. 3, Part iii. Superintendent of Government Printing Press.

Holmes, J. (2008). An introduction to socio-linguistics (3rd ed.). Longman.

Hudson, R. A. (1996). Sociolinguistics (2nd ed.). CUP.

Kainla, B. (ed.). (2059VS). Limbu-Nepali-Angreji Sabdakosh. Nepal Rajkiya Pragya Pratishthan (Royal Nepal Academy).

Lazar, G. (2004). Literature and language teaching: A guide for teachers and trainers. CUP.

Leech, G. N. (1988). A linguistic guide to English poetry. Longman.

Central bureau of statistics. (2011). Ministry of Environment and Population (MOEP).

Nicoletti, M. (2006). Ancestral forest: Memory, space and ritual among the Thulung Rai of eastern Nepal. Vajra Publication.

Pokharel, M. P. (2050VS). Nepal ko bhashama Limbu bhasha. Limbu bhasha sahitya bichar goshthi [Limbu language and literary symposium]. (pp. 22-31). Nepal Rajkiya Pragya Pratishthan (Royal Nepal Academy).

Pope, A. (1991). An assay on criticism. In Enright, D. J. \& Chickera, E. De. (Ed.). English critical texts. (pp. 111-130). OUP.

Pope, R. (2010). The English studies book: An introduction to language, literature and culture. Routledge.

Simpson, P. (2012). Stylistics: A resource book for students. Routledge.

Shklovsky, V. (1917). Art as technique. Trans. Lee T. Lemon and Marion J. Reis. (Eds.). Russian formalist criticism: Four essays. (pp. 5-24). Reprinted by Permission of the University of Nebraska Press (UNP) 1965.

Subba, C. (1995). The culture and religion of Limbus. K. B. Subba.

Tumbahang, G. B. (2007). A descriptive grammar of Chhathare Limbu. (An Unpublished PhD Dissertation) T.U. Department of English, Faculty of Humanities and Social Sciences.

Tumbahang, M. K. (2013). A linguistic study of Limbu Mundhum. (An Unpublished PhD Dissertation). T.U. Department of Linguistics, Faculty of Humanities and Social Sciences.

Weidert, A. \& Subba, B. (1985). Concise Limbu grammar and dictionary. Lobster Publication.

Widdowson, H. G. (1983). The deviant language of poetry. In Brumfit, C. J. (Ed.). Teaching literature overseas: Language based approaches. (pp. 7-16). Pergamon.

Yule, G. (1995). The study of language. CUP. 